Check for updates

Cite this: RSC Adv., 2018, 8, 170

Received 12th October 2017

Accepted 8th December 2017

DOI: $10.1039 / c 7 r a 11259 a$

rsc.li/rsc-advances

\title{
A efficient protocol for the synthesis of thioamides in [DBUH][OAc] at room temperature $\uparrow$
}

\author{
Xian-Ting Cao, (D) ${ }^{a b}$ Li Qiao, ${ }^{b}$ Hui Zheng, ${ }^{b}$ Hui-Yong Yang ${ }^{b}$ and Peng-Fei Zhang*ab \\ A novel, simple and eco-friendly method to synthesize thioamides from aryl nitriles and sodium sulfide \\ $\left(\mathrm{Na}_{2} \mathrm{~S} \cdot 9 \mathrm{H}_{2} \mathrm{O}\right)$ catalyzed by 1,8 -diazabicyclo[5,4,0]undec-7-enium acetate ([DBUH][OAc]) ionic liquid (IL) \\ at room temperature was developed in this paper. In this reaction, readily available inorganic salt \\ $\left(\mathrm{Na}_{2} \mathrm{~S} \cdot 9 \mathrm{H}_{2} \mathrm{O}\right)$ serves as the sulfur source, and various functional groups of aryl nitriles were well tolerated \\ at room temperature. In addition, the products were easily separated from the IL which could be reused \\ at least five times without considerable loss of its activity and applied in the green, concise synthesis of \\ ethionamide.
}

\section{Introduction}

Thioamides and their derivatives are useful synthons and reaction partners in organic chemistry, and often found in vital biological and pharmaceutical molecules. ${ }^{1}$ Meanwhile, as important building blocks, they are applied broadly in the areas of synthesis of many significant sulfur-containing heterocycles, such as thiazolines, thiazoles, thiazolinones, thiadiazoles, tetrazoles, mesoionic rhodanine, betaines and other heterocyclic. $^{2-10}$ Therefore, the synthesis of thioamides which have received extensive attention. Consequently, a number of synthesis methods have been developed for the thioamides using various reagents under diverse reaction conditions. ${ }^{\mathbf{1 1 - 1 8}}$ Conventionally, alternative sulfur sources such as Lawesson's reagent and its analogues are applied to the synthesis of thioamides (Scheme 1a). ${ }^{19-21}$ Similarly, sulfur-phosphorus-type reagents have been developed for the synthesis of thioamides through nitriles or amides and carboxylic acids (Scheme 1a). ${ }^{22-31}$ However, these traditional methods often require harsh reaction conditions and the yields are typically low, such as high temperature, the use of toxic and high boiling solvents, and moreover, suffer from a narrow substrate scope. Following the guidance of green chemistry, find an environment-friendly way to synthesize thioamides is considered of high practical value.

Using ionic liquid as a solvent for organic reactions is a very interesting and attractive topic because it is both convenient and environmentally friendly. Ionic liquids becoming an effective medium in organic synthesis. In view of this, herein, we would like to report a simple green method for the synthesis of

${ }^{a}$ College of Pharmaceutical Science, Zhejiang University of Technology, Hangzhou 310014, China

${ }^{b}$ College of Material, Chemistry and Chemical Engineering, Hangzhou Normal University, Hangzhou, 310016, China

$\dagger$ Electronic supplementary information (ESI) available. See DOI: $10.1039 / \mathrm{c} 7 \mathrm{ra} 11259 \mathrm{a}$ the thioamides based on the novel recyclable ionic liquid [DBUH][OAc] via reaction of cheap, easily available sodium sulfide $\left(\mathrm{Na}_{2} \mathrm{~S} \cdot 9 \mathrm{H}_{2} \mathrm{O}\right)$ and nitriles at room temperature (Scheme 1b).

\section{Result and discussion}

Initially, we initiated the optimization of the reaction on simple benzonitrile (1a) (Table 1). Reaction of Benzonitrile 1a with $S_{8}$ in the presence of bases (entries 1-7) in different solvents at room temperature, there are no the desired thiobenzamide 2a product generated. Similarly, when 1 a with $\mathrm{S}_{8}$ in $[\mathrm{DBUH}][\mathrm{OAc}]$ at room temperature also no reaction (entry 8). Treatment of benzonitrile with other $\mathrm{S}$ source, carbon disulfide $\left(\mathrm{CS}_{2}\right)$, in $[\mathrm{DBUH}][\mathrm{OAc}]$ at room temperature provided the desired thiobenzamide $\mathbf{2 a}$ in $31 \%$ yield (entry 1 ). When the same reaction was carried out at a higher temperature $\left(40{ }^{\circ} \mathrm{C}\right)$, the yield $(42 \%)$ was not improved significantly. Use of $\mathrm{Na}_{2} \mathrm{~S} \cdot 9 \mathrm{H}_{2} \mathrm{O}$ as S source in solvents (entries 11-16) at room temperature, the product thiobenzamide 2 a were not found. Use of $\mathrm{Na}_{2} \mathrm{~S} \cdot 9 \mathrm{H}_{2} \mathrm{O}$ in the presence of [DBUH] [OAc] was able to give he desired product (entry 19) in $88 \%$ yield; however, $\mathrm{Na}_{2} \mathrm{~S} \cdot 9 \mathrm{H}_{2} \mathrm{O}$ in the presence of solvents provided thiobenzamide $2 \mathrm{a}$ in lower yield (entries 17 and 18). In order to examine the activity of different ionic liquids benzonitrile $1 \mathrm{a}$ was caused to react with $\mathrm{Na}_{2} \mathrm{~S} \cdot 9 \mathrm{H}_{2} \mathrm{O}$ in the presence of each ionic liquid separately, as shown in Table 1 (entries 19-21), [DBUH][OAc] is the most effective in terms of yield of the corresponding thioamide (88\%), the results show that the activities of the ILs depend on both their anions and cations, The [DBUH][OAc] and [BMim][OOAc] with an $\mathrm{Ac}^{-}$anion can promote for the reaction, the major reason was that acetic acid is a weak acid and so the ILs are bases, and basic catalysis can promote the reaction. Meanwhile, the cations of the ILs also influenced reaction significantly, the excellent activity of the $[\mathrm{DBUH}][\mathrm{OAc}]$ may result from their optimal basicity for the 
(a) Previous works

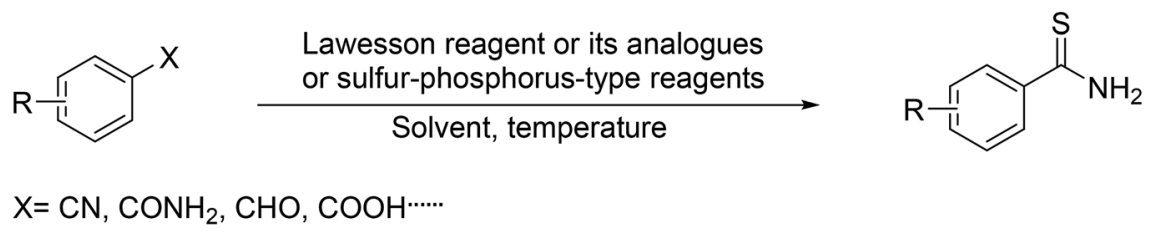

(b)This work

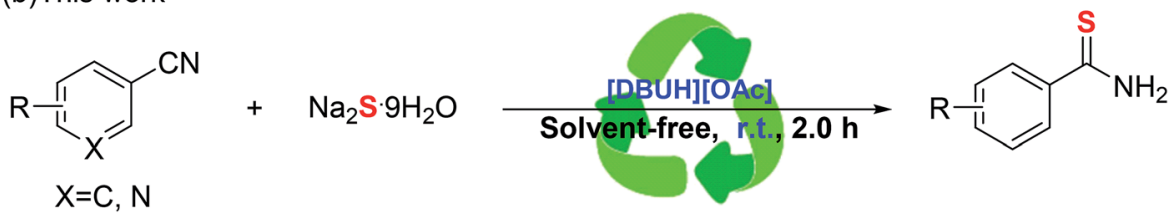

Scheme 1

reaction. ${ }^{32}$ Treatment of benzonitrile 1a with $\mathrm{Na}_{2} \mathrm{~S}$ in [DBUH] [OAc] at room temperature for $2 \mathrm{~h}$ gave the desired thiobenzamide 2a product in a very trace amount, however, when no water was added, it furnished thiobenzamide $2 \mathrm{a}$ in $82 \%$ yield (entry 23), the result show that water is necessary. In general, the optimum conditions were $2 \mathrm{~h}$ at room temperature in the presence of $[\mathrm{DBUH}][\mathrm{OAc}]$ for this reaction.

Table 1 Optimization of the reaction conditions

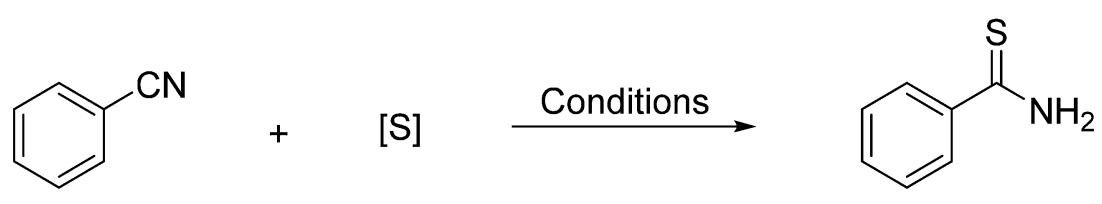

$1 a$
$2 a$

\begin{tabular}{|c|c|c|c|c|}
\hline $1^{a}$ & $\mathrm{~S}_{8}$ & $\mathrm{Na}_{2} \mathrm{CO}_{3}$ & $\mathrm{H}_{2} \mathrm{O}$ & 0 \\
\hline $2^{a}$ & $\mathrm{~S}_{8}$ & $\mathrm{~K}_{2} \mathrm{CO}_{3}$ & $\mathrm{H}_{2} \mathrm{O}$ & 0 \\
\hline $4^{a}$ & $\mathrm{~S}_{8}$ & DBU & $\mathrm{H}_{2} \mathrm{O}$ & 0 \\
\hline $5^{a}$ & $\mathrm{~S}_{8}$ & DBU & $\mathrm{AcOH}$ & 0 \\
\hline $6^{a}$ & $\mathrm{~S}_{8}$ & DBU & $\mathrm{DMF}$ & 0 \\
\hline $9^{c}$ & $\mathrm{CS}_{2}$ & {$[\mathrm{DBUH}][\mathrm{OAc}]$} & - & 31 \\
\hline $10^{c, f}$ & $\mathrm{CS}_{2}$ & {$[\mathrm{DBUH}][\mathrm{OAc}]$} & - & 42 \\
\hline $11^{c}$ & $\mathrm{Na}_{2} \mathrm{~S} \cdot 9 \mathrm{H}_{2} \mathrm{O}$ & - & $\mathrm{H}_{2} \mathrm{O}$ & 0 \\
\hline $12^{c}$ & $\mathrm{Na}_{2} \mathrm{~S} \cdot 9 \mathrm{H}_{2} \mathrm{O}$ & - & DMSO & 0 \\
\hline $13^{c}$ & $\mathrm{Na}_{2} \mathrm{~S} \cdot 9 \mathrm{H}_{2} \mathrm{O}$ & - & DMF & 0 \\
\hline $14^{c}$ & $\mathrm{Na}_{2} \mathrm{~S} \cdot 9 \mathrm{H}_{2} \mathrm{O}$ & - & NMP & 0 \\
\hline $19^{d}$ & $\mathrm{Na}_{2} \mathrm{~S} \cdot 9 \mathrm{H}_{2} \mathrm{O}$ & [DBUH][OAc] & - & 88 \\
\hline $20^{d}$ & $\mathrm{Na}_{2} \mathrm{~S} \cdot 9 \mathrm{H}_{2} \mathrm{O}$ & {$[\mathrm{BMIm}][\mathrm{OAc}]$} & - & 38 \\
\hline $21^{d}$ & $\mathrm{Na}_{2} \mathrm{~S} \cdot 9 \mathrm{H}_{2} \mathrm{O}$ & {$[\mathrm{BMIm}]\left[\mathrm{PF}_{6}\right]$} & - & Trace \\
\hline $22^{d}$ & $\mathrm{Na}_{2} \mathrm{~S}$ & {$[\mathrm{DBUH}][\mathrm{OAc}]$} & - & Trace \\
\hline $23^{d}$ & $\mathrm{Na}_{2} \mathrm{~S}$ & {$[\mathrm{DBUH}][\mathrm{OAc}]$} & $\mathrm{H}_{2} \mathrm{O}$ & $82^{\circ}$ \\
\hline
\end{tabular}

${ }^{a}$ Reaction conditions: $1 \mathrm{a} 1.0 \mathrm{mmol}, \mathrm{S}_{8} 3.0 \mathrm{mmol}$, additive $3.0 \mathrm{mmol}$, solvent $0.6 \mathrm{~mL}$, r.t., 2 h. ${ }^{b}$ Reaction conditions: 1 a $1.0 \mathrm{mmol}$, $\mathrm{S}_{8} 3.0 \mathrm{mmol}$, additive $3.0 \mathrm{mmol}$, r.t., 2 h. ${ }^{c}$ Reaction conditions: $1 \mathrm{a} 1.0 \mathrm{mmol}, \mathrm{Na}_{2} \mathrm{~S} \cdot 9 \mathrm{H}_{2} \mathrm{O} 1.2 \mathrm{mmol}$, solvent $1 \mathrm{~mL}$, r.t., 2 h. ${ }^{d}$ Reaction conditions: $1 \mathrm{a}$ $1.0 \mathrm{mmol}$, S source $1.2 \mathrm{mmol}$, additive $3.0 \mathrm{mmol}$, solvent $0.3 \mathrm{~mL} .{ }^{e}$ Isolated yield. ${ }^{f}$ The reaction was run at $40^{\circ} \mathrm{C}$. 
Table 2 Substrate scope for the thioamides ${ }^{a, b}$

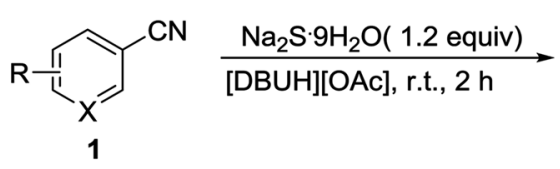

$\mathrm{X}=\mathrm{C}, \mathrm{N}$<smiles>[R][X]1ccc(C(N)=S)cc1</smiles><smiles>COc1ccc(C(N)=S)cc1</smiles>

2e, $76 \%$<smiles>NC(=S)c1ccc(I)cc1</smiles>

2i, $85 \%$<smiles>NC(=S)c1ccc(C(F)(F)F)cc1</smiles>

2m, $70 \%$<smiles>NC(=S)c1ccc(-c2ccccc2)cc1</smiles>

$2 q, 70 \%$<smiles>NC(=S)c1ccccn1</smiles>

2u, $75 \%$<smiles>Cc1ccc(C(N)=S)cc1</smiles>

2b, $88 \%$<smiles>Cc1cccc(C(N)=S)c1</smiles>

2c, $85 \%$<smiles>NC(=S)c1ccc(Cl)cc1</smiles>

2g, $90 \%$<smiles>NC(=S)c1ccccc1F</smiles>

2j, $70 \%$<smiles>NC(=S)c1ccc(OC(F)(F)F)cc1</smiles>

2n, $83 \%$<smiles>NC(=S)c1ccc2ccccc2c1</smiles>

2r, $81 \%$<smiles>NC(=S)c1ccncc1</smiles>

$2 \mathbf{v}, 78 \%$<smiles>NC(=S)c1cccc(F)c1</smiles>

2k, $89 \%$<smiles>NC(=S)c1ccccc1OC(F)(F)F</smiles>

2o, $81 \%$<smiles>NC(=S)c1cccc2ccccc12</smiles>

2s, $78 \%$<smiles>Cc1cccc(C(N)=S)n1</smiles>

2w, $81 \%$<smiles>COc1ccccc1C(N)=S</smiles>

2d, $77 \%$<smiles>NC(=S)c1ccc(Br)cc1</smiles>

2h, $86 \%$<smiles>N#Cc1ccc(C(N)=S)cc1</smiles>

2l, $75 \%$<smiles>NC(=S)c1cccc(OC(F)(F)F)c1</smiles>

2p, $80 \%$<smiles>NC(=S)c1cccnc1</smiles>

2t, $75 \%$<smiles>CC(C)(C)c1ccc(C(N)=S)cc1</smiles>

$2 x, 85 \%$<smiles>N#Cc1ccc(C(c2ccc(C(N)=S)cc2)n2cncn2)cc1</smiles>

$2 y, 64 \%^{g}$<smiles>NC(=S)c1ccc(C(c2ccc(C(N)=S)cc2)n2cncn2)cc1</smiles>

2z, $73 \%^{h}$

${ }^{a}$ Reaction conditions: 1 (1 mmol), $\mathrm{Na}_{2} \mathrm{~S} \cdot 9 \mathrm{H}_{2} \mathrm{O}(1.2 \mathrm{mmol})$, [DBUH] [OAc] $(3 \mathrm{mmol})$, r.t. 2 h. ${ }^{b}$ Isolated yield. ${ }^{c}$ Yield of the product (runs: 2). ${ }^{d}$ Yield of the product (runs: 3). ${ }^{e}$ Yield of the product (runs: 4$) .{ }^{f}$ Yield of the product (runs: 5). ${ }^{g}$ Reaction conditions: $\mathbf{1}(0.5 \mathrm{mmol}), \mathrm{Na}_{2} \mathrm{~S} \cdot 9 \mathrm{H}_{2} \mathrm{O}(0.6 \mathrm{mmol})$.

${ }^{h}$ Reaction conditions: 1 ( $\left.0.5 \mathrm{mmol}\right), \mathrm{Na}_{2} \mathrm{~S} \cdot 9 \mathrm{H}_{2} \mathrm{O}(1.2 \mathrm{mmol})$. 


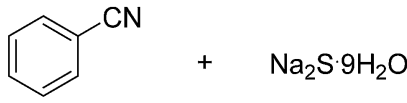

$10.0 \mathrm{mmol}$ $1.03 \mathrm{~g}$
Solvent-free [DBUH][OAc], r.t., $2 \mathrm{~h}$<smiles>NC(=S)c1ccccc1</smiles>

2a, $1.08 \mathrm{~g}$ $79 \%$

Scheme 2 A gram-scale reaction.<smiles>CCc1cc(Cl)ccn1</smiles>

$5.0 \mathrm{mmol}$ $+\quad \mathrm{Na}_{2} \mathrm{~S} \cdot 9 \mathrm{H}_{2} \mathrm{O}$

[DBUH][OAc], r.t., $2 \mathrm{~h}$<smiles>CCc1cc(C(N)=S)ccn1</smiles>

ethionamide $80 \%, 0.67 \mathrm{~g}$

Scheme 3 Application of the reaction.

In order to expand the scope of this system, various aromatic or heterocyclic nitriles were then examined (Table 2). The experimental results disclosed that the substrates bearing electron donating or electron withdrawing groups underwent this reaction to produce thioamides in moderate to high yields (70-91\%). The substrate bearing the electron-donating group $\mathrm{CH}_{3}$ reacted smoothly with yields of up to $88 \%$ (Table $2,2 \mathbf{b}, 2 \mathbf{c}$ ). The substrate bearing the electron-withdrawing group $\mathrm{CN}$ and $\mathrm{CF}_{3}$ also reacted well with yields of up to $75 \%$ (Table 2, 2l, 2m). The coupling of heteroaryl nitriles with $\mathrm{Na}_{2} \mathrm{~S} \cdot 9 \mathrm{H}_{2} \mathrm{O}$ also performed well (Table 2, $2 \mathbf{t}, \mathbf{2 \mathbf { u }}, \mathbf{2 \mathbf { v }}$ and $\mathbf{2 w}$ ). Letrozole is an orally active nonsteroidal aromatase inhibitor for the treatment of hormonally-responsive breast cancer after surgery, and it has two "CN" functional groups, the product $2 \mathbf{y}(64 \%)$ was obtained when 1.2 equiv. of $\mathrm{Na}_{2} \mathrm{~S} \cdot 9 \mathrm{H}_{2} \mathrm{O}$ was used. However, when the amount of $\mathrm{Na}_{2} \mathrm{~S} \cdot 9 \mathrm{H}_{2} \mathrm{O}$ was increased to 2.4 equiv., the product $2 \mathbf{z}$ was obtained with $73 \%$ yield. In general, it can be concluded from the results that the IL ([DBUH][OAc]) had broad applicability to substrates in this reaction.

Significantly, the IL ([DBUH][OAc]) used in this reaction was found to remain catalytic ability after being three times. Yet the product yields only decline slightly (reducing from $88 \%$ in the first run to $83 \%$ in the five run). This result indicated that this system was recyclable for catalyzing the reaction of $\mathrm{Na}_{2} \mathrm{~S} \cdot 9 \mathrm{H}_{2} \mathrm{O}$ with aryl nitriles.

So as to embody the application value of the method, we performed a gram-scale reaction (Scheme 2), the product 2a was easily obtained in $79 \%$ yield under the $[\mathrm{DBUH}][\mathrm{OAc}]$ ionicliquid at room temperature.

With the effective method of thioamides in hand, we next inspected the applicability of this method to prepare ethionamide which is an antibiotic used to treat tuberculosis.

Fortunately, the synthesis of compound ethionamide was successful proceed under optimum conditions, and the target product was acquired in $80 \%$ yield (Scheme 4 ).

Importantly, the products were easily afford pure thioamides. The present reaction provides a simple and straightforward access from readily available materials (nitriles, and $\mathrm{Na}_{2} \mathrm{~S} \cdot 9 \mathrm{H}_{2} \mathrm{O}$ ) to thioamides, which permits rapid access to various important compounds. For instance, the 1,2,4-thiadiazole 3a was isolated in 95\% yield (Scheme 3a), ${ }^{33}$ Moreover, styrene with NBS and subsequent addition of thiobenzamide 2a in water provided 2,4-diarylsubstituted thiazole $4 a$ in $72 \%$ yield (Scheme 3b). ${ }^{34}$ Furthermore, thiobenzamide 2a with iodobenzene to provide $5 \mathrm{a}$ in $57 \%$ yield, (Scheme $3 \mathrm{c}$ ). ${ }^{35}$

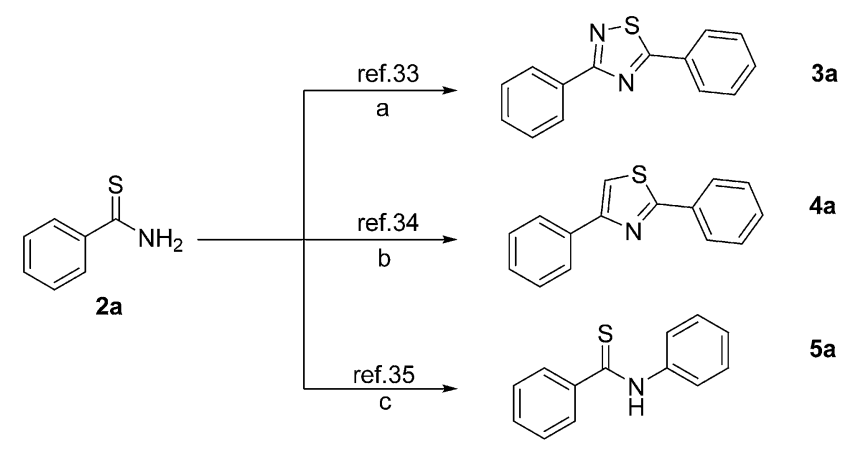

Scheme 4 Applications to thioamides.

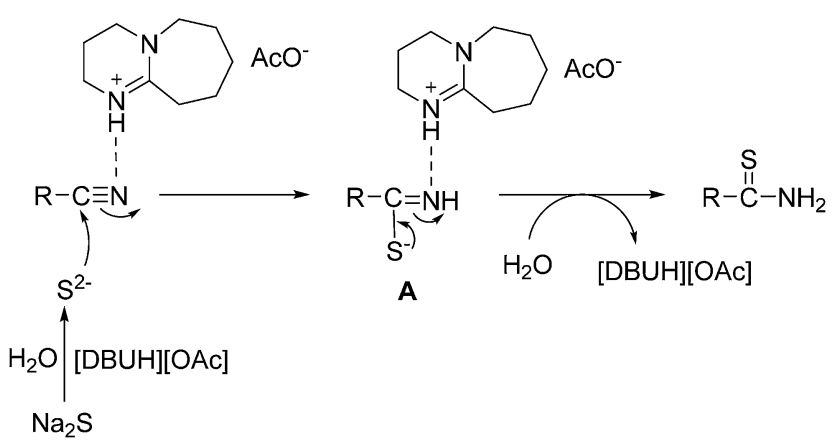

Scheme 5 The possible reaction pathway. 


\section{Reaction mechanism}

A plausible pathway was outlined in Scheme 5 . The $[\mathrm{DBUH}]^{+}$ made the cyanide activated, the $\mathrm{S}^{2-}$ with the nitrile to yield intermediate A. Finally, the final product thioamides are obtained from the intermediate $\mathrm{A}$.

\section{Conclusion}

In summary, we have developed an efficient [DBUH][OAc]promoted the reaction of different aryl nitriles with $\mathrm{Na}_{2} \mathrm{~S} \cdot 9 \mathrm{H}_{2}$ $\mathrm{O}$ as an inexpensive, conveniently available and easy-to-handle sulfide surrogate under solvent-free conditions at room temperature. The generated products were easily separated from the ILs which could be reclaimed at least five times. The operational environmental friendliness and simplicity of this method highlights its potential application in organic synthesis and pharmaceutical industry.

\section{Experimental}

General procedure for preparation of ionic liquid [DBUH][OAc]: to a $250 \mathrm{~mL}$ three-necked flask was added $40 \mathrm{mmol}$ of DBU. Acetic acid (40 mmol) was then added slowly dropwise in ice bath. After dropwise addition, the ice bath was removed and the reaction mixture was stirred at room temperature for $24 \mathrm{~h}$. The oil residue was dried in vacuo at $60{ }^{\circ} \mathrm{C}$ for $24 \mathrm{~h}$ to afford [DBU] [OAc] as a light yellow, viscous liquid. The characteristic data is accord with the literature. ${ }^{36}$

The general procedure of preparing all products is similar. Taking the model reaction as an example: benzonitrile 1a (1 $\mathrm{mmol})$ and [DBUH] [OAc] $(3 \mathrm{mmol})$ were added into a $10 \mathrm{~mL}$ bottle. After $2.0 \mathrm{~h}$, by adding about $4 \mathrm{~mL} \mathrm{H}_{2} \mathrm{O}$ after the reaction to disperse the solid product, the reaction mixture was extracted with ethyl acetate $(3 \times 4 \mathrm{~mL})$ followed by $\mathrm{H}_{2} \mathrm{O}(5 \mathrm{~mL})$, and the mixture was purified by column chromatography.

\section{Conflicts of interest}

There are no conflicts to declare.

\section{Acknowledgements}

We are grateful to the Major scientific and technological innovation projects of Hangzhou City (No. 20162011A036) and the Program for Changjiang Scholars and Innovative Research Team in Chinese University (IRT 1231) for providing financial support.

\section{References}

1 F. Wang, R. Langley, G. Gulten, L. G. Dover, G. S. Besra, W. R. Jacobs Jr and J. C. Sacchettini, J. Exp. Med., 2007, 204, 73-78.

2 T. S. Jagodzinski, Chem. Rev., 2003, 103, 197-228.

3 P. Wipf and S. A. Venkatraman, J. Org. Chem., 1996, 61, 80048005.
4 D. Kumar, N. M. Kumar, K. H. Chang, R. Gupta and K. Shah, Bioorg. Med. Chem. Lett., 2011, 21, 5897-5900.

5 L. M. T. Frija, A. J. L. Pombeiro and M. N. Kopylovich, Eur. J. Org. Chem., 2017, 2017, 2670-2682.

6 O. A. Attanasi, S. Berretta, L. D. Crescentini, G. Favi, P. Filippone, G. Giorgi, S. Lillini and F. Mantellini, Tetrahedron Lett., 2007, 48, 2449-2451.

7 A. S. Gurjar, V. Andrisano, A. D. Simone and V. S. Velingkar, Bioorg. Chem., 2014, 57, 90-98.

8 G. L. Perlovich, A. N. Proshin, T. V. Volkova, L. N. Petrova and S. O. Bachurin, Mol. Pharmaceutics, 2012, 9, 2156-2167.

9 A. S. Mayhoub, L. Marler, T. P. Kondratyuk, E. J. Park, J. M. Pezzuto and M. Cushman, Bioorg. Med. Chem., 2012, 20, 510-520.

10 Y. Sun, W. Wu and H. Jiang, Eur. J. Org. Chem., 2014, 2014, 4239-4243.

11 H. Xu, H. Deng, Z. Li, H. Xiang and X. Zhou, Eur. J. Org. Chem., 2013, 7054-7057.

12 K. A. Mahammed, V. P. Jayashankar, N. Premsai Rai, K. Mohana Raju and P. N. Arunachalam, Synlett, 2009, 14, 2338-2340.

13 M. L. Boys and V. L. Downs, Synth. Commun., 2006, 36, 295298.

14 T. Kanbara, K. Okamoto and T. Yamamoto, Synlett, 2007, 2007, 2687-2690.

15 C. K. Khatri, A. S. Mali and G. U. Chaturbhuj, Monatsh. Chem., 2017, 148, 1463-1468.

16 A. Manaka and M. Sato, Synth. Commun., 2005, 35, 761-764.

17 S. Ray, A. Bhaumik, A. Dutta, R. J. Butcher and C. Mukhopadhyay, Tetrahedron Lett., 2013, 54, 2164-2170.

18 Z. Yin and B. Zheng, J. Sulfur Chem., 2013, 34, 527-531.

19 Z. Kaleta, G. Tárkányi, A. Görmory, F. Kálmán, T. Nagy and T. Soós, Org. Lett., 2006, 8, 1093-1095.

20 U. Pathak, L. Pandey, S. Mathur and M. Suryanarayana, Synthesis, 2011, 44, 377-379.

21 C.-H. Yang, G.-J. Li, C.-J. Gong and Y.-M. Li, Tetrahedron, 2015, 71, 637-642.

22 T. J. Curphe, J. Org. Chem., 2002, 67, 6461-6473.

23 J. Bergman, B. Pettersson, V. Hasimbegovic and P. H. Svensson, J. Org. Chem., 2011, 76, 1546-1553.

24 D. Cho, J. Ahn, K. A. De Castro, H. Ahn and H. Rhee, Tetrahedron, 2010, 66, 5583-5588.

25 L. Doszczak and J. Rachon, Chem. Commun., 2000, 20932094.

26 S. Goswami, A. C. Maity and N. K. Das, J. Sulfur Chem., 2007, 28, 233-237.

27 B. Kaboudin and D. Elhamifar, Synthesis, 2006, 224-226.

28 B. Kaboudin and L. Malekzadeh, Synlett, 2011, 2011, 28072810.

29 B. Kaboudin, V. Yarahmadi, J.-y. Kato and T. Yokomatsu, RSC Adv., 2013, 3, 6435.

30 H. R. Lagiakos, A. Walker, M.-I. Aguilar and P. Perlmutter, Tetrahedron Lett., 2011, 52, 5131-5132.

31 A. K. Yadav, V. P. Srivastava and L. D. S. Yadav, Synth. Commun., 2013, 44, 408-416.

32 W. Lu, J. Ma, J. Hu, J. Song, Z. Zhang, G. Yang and B. Han, Green Chem., 2014, 16, 221-225. 
33 M. H. Shinde and U. A. Kshirsagar, Green Chem., 2016, 18, 35 G. Vanajatha and V. P. Reddy, Tetrahedron Lett., 2016, 57, 1455-1458. 2356-2359.

34 K. Swapna, S. N. Murthy and Y. V. D. Nageswar, Eur. J. Org. 36 A. Ying, L. Liu, G. Wu, G. Chen, X. Chen and W. Ye, Chem., 2010, 2010, 6678-6684. Tetrahedron Lett., 2009, 50, 1653-1657. 